\title{
The Analysis of Geospatial Information for Validating Some Numbers of Islands in Indonesia
}

\author{
Sukendra Martha
}

Received: August 2016/ Accepted: January 2017 / Published online: December 2017

(c) 2017 Faculty of Geography UGM and The Indonesian Geographers Association

\begin{abstract}
This article discusses a comparison of various numbers of islands in Indonesia; and it addresses a valid method of accounting or enumerating numbers of islands in Indonesia. Methodology used is an analysis to compare the different number of islands from various sources. First, some numbers of Indonesian islands were derived from: (i) Centre for Survey and Mapping- Indonesian Arm Forces (Pussurta ABRI) recorded as 17,508 islands; (ii) Agency for Geospatial Information (BIG) previously known as National Coordinating Agency for Surveys and Mapping (Bakosurtanal) as national mapping authority reported with 17,506 islands (after loosing islands of Sipadan and Ligitan); (iii) Ministry of Internal Affair published 17,504 islands. Many parties have referred the number of 17,504 islands even though it has not yet been supported by back-up documents; (iv) Hidrographic Office of Indonesian Navy has released with numbers of 17,499; (v) Other sources indicated different numbers of islands, and indeed will imply to people confusion. In the other hand, the number of 13,466 named islands has a strong document (Gazetteer). Second, enumerating the total number of islands in Indonesia can be proposed by three ways: (i) island census through toponimic survey, (ii) using map, and (iii) applying remote sensing images. Third, the procedures of searching valid result in number of islands is by remote sensing approach - high resolution satellite images. The result of this work implies the needs of one geospatial data source (including total numbers of islands) in the form of 'One Map Policy' that will impact in the improvement of Indonesian geographic data administration.
\end{abstract}

Keywords: number of Indonesian islands, island definition, method for counting islands.

\begin{abstract}
Abstrak Makalah ini mengungkapkan perbandingan angka jumlah pulau Indonesia yang beragam dan mendiskusikan teknik penghitungan yang valid tentang jumlah pulau di Indonesia. Metodologi yang digunakan adalah kajian perbandingan angka jumlah pulau dari berbagai sumber. Pertama, Perbandingan angka jumlah pulau di Indonesia yang diperoleh dari: (i) Pusat Survei dan Pemetaan ABRI (Pussurta ABRI) mencatat sebanyak 17.508 pulau; (ii) Badan Informasi Geospasial (BIG) yang dulu bernama Badan Koordinasi Survei dan Pemetaan Nasional (Bakosurtanal) sebagai lembaga nasional yang memiliki otoritas dalam bidang informasi geospasial, pernah melaporkan angka 17.506 (setelah hilangnya P. Sipadan dan P. Ligitan); (iii) Kementerian Dalam Negeri yang memunculkan angka 17.504 yang sering dijadikan acuan banyak pihak walaupun juga belum ada data pendukung yang kuat sebagai 'back-up; (iv) Dinas Hidro-oseanografi TNI-AL yang merelease angka 17.499 pulau; (v) Sumber lain menunjukkan angka yang berbeda, dan tentu saja dapat membingungkan masyarakat. Sementara angka 13.466 pulau bernama yang dihasilkan dari survei toponimi pulau, memiliki dokumen kuat berupa 'Gazetteer'. Kedua, penghitungan angka jumlah pulau diusulkan dapat dilakukan dengan tiga cara: (i) sensus pulau melalui survei toponimi, (ii) pemanfaatan peta, dan (iii) penggunaan citra penginderaan jauh. Ketiga, hasil penelusuran yang valid terhadap angka jumlah pulau adalah dengan pendekatan penginderaan jauh beresolusi tinggi yang terkoreksi secara geometrik. Hasil kajian ini mengimplikasikan perlunya satu sumber data geospasial (termasuk angka jumlah pulau) dalam bentuk 'One Map Policy' yang berdampak dalam perbaikan administrasi data geografi wilayah NKRI.
\end{abstract}

Kata kunci: jumlah pulau Indonesia, definisi pulau, metode penghitungan pulau.

\section{Introduction}

Number of islands in Indonesia is usually become an interesting topic to be discussed by many scholars, experts and others. Indonesia as an Archipelagic States, and particularly as Maritime Country has own land including areas and islands that extend and distribute all over the country. Such distributed islands need also to contribute people prosperity. Island inventory

\footnotetext{
Sukendra Martha

Geospatial Information Agency, National Resilience Institute of the Republic of Indonesia (Lembaga Ketahanan Nasional RI)

Correspondent email: sukendramartha@yahoo.co.id
}

is important to determine number of island and its resource potential in Indonesian situation. In this case potency of life and non-life resources that are owned by islands need to be properly managed, inventoried and mapped [Abidin, 2015]. Mapping works and geospatial information sometimes are not used properly.

The Minister of Marine and Fishery Republic of Indonesia, Susi Pudjiastuti stated that so many variety of resources (including islands) and broad coverage of the sea that are managed without map [BIG dan IGI, 2015]. As an archipelagic state and maritime country, 
Indonesia has to prove the owner of more than 17,000 islands. To become a big and strong maritime country, Indonesia has to manage its territory very well [Pailah, 2009, Lemhannas, 2015] while some assets in the form of islands distributed in Indonesian waters has not been formally determined yet. The number of island is not only limited to the recognition and claims but also need to have a fix number based on accounting supported by legal documents and proves for public in national or international level. Certainly, Indonesia has owned numbers of island and should declare as the same as he recognized.

The importance of island number here is due several interests involved in: (a). National development, that needs all areas including islands are the object to be built and managed, (b). Defense and security, to provide ascertain of all national territory, both land and water, sea and together with existing islands; and (c). Boundary demarcation of Indonesian territory to fix the total area and existing islands including the outer islands that are part of the area. Existing islands in Indonesian territory is an integrated part of archipelagic state or maritime country [Sebastian, 2015; Mangan, et al., 2013].

This paper analysis data on the various numbers of island in Indonesia at the present time. This is because there has been no research or analysis done to report the fixed number of island supported by its method of reanumeration. Indonesian people has right to know the number of island as public information. It's time for the Government to provide information about the number of island as his responsibility for the public. Center Bureau of Statistics or Badan Pusat Statistik (BPS) that has to be responsible for all statistical data in Indonesia, has not provided figure of number of island, even in the latest report of National Census 2010. The reason is that BPS is responsible for all statistical data in the country, but not geospatial data which is responsibility of BIG. Figure on island number is geospatial data. Meaning that, the accountability of counting process is not part of the BPS tasks, but when data become an output to be reported then BPS will take responsibility.

Unfortunately, geospatial data on island number have not been centrally published and declared. Many people wanted to know the actual number of island because the figure of number of island is important to know. The figure or number of islands is required for the national statistics that will benefit for country administration. For the national leaders and candidates of national leaders, the figure of island in Indonesia should become an important geographical statistics to understand the whole Indonesian geography. The first President of the Republic of Indonesia, Soekarno on the event of opening speech in launching Lemhannas in May, 20, 1965, stated:

"In National Defense Institute that I approved, given lectures to all followers, in order to really understand, our fatherland, geography of our fatherland, constellation of our fatherland, our people origin, our people mentality, our economy, our culture, all of these will process to become material for formulating and determining our national defense".

The speech delivered by President Soekarno was a reflection of Djuanda Declaration in 1957. President Soekarno urged all Lemhannas participants (at that time the name was used as Lembaga Pertahanan Nasional), or National Defense Institute, (not Resilience) to remind and follow the example of founding father in struggling for the independence. Founding father emphasized that with all other aspects, geography and geographic constellation needed to be understood and be part of the national defense. Furthermore, geography of Indonesia has to be pay attention as national awareness, and one of the geographical awareness is the concern on the islands. The continuation of such struggle values should be inherited from generation to generation and aware of the importance of Indonesian geography [Martha, 2012, 2014]. In other words, from the beginning geography is considered to be important, therefore to learn Geography, map is an important tool to understand. Therefore, to read Indonesian map is needed to understand Indonesian territories [Martha, 2013]. Geographical awareness can be improved after seeing, visiting many different areas in Indonesia. This off course, field observation and study tour will improve regional knowledge and hopefully can improve geographical awareness. Geographical awareness of the nation is considered to be low [Suradinata, 2005]. Therefore, it can be improved through understanding of Indonesian geography, including Indonesian boundaries and geographical potency including existing number of islands [Martha, 2013]. The question is how to validate the different figures of island numbers.

\section{The Methods}

Methods used in this analysis are:

(1) Literature study to obtain data on island number in Indonesia.

(2) Analysis is conducted by comparative test, that compares all numbers of islands. Analysis is also done towards the variety differences of island number in Indonesia derived from various sources.

The phase of analysis includes collection of data or number of islands from various sources, then it composed in the form of Comparison Table on Table 1 as sources of analysis. Furthermore, at the end of analysis, discussion will come to propose some alternative ways to calculate the number of islands.

In this analysis, data sources are media or 
publication come from Governmental agencies or private sectors. Media sources that report the number of island Gazetteer from Bakosurtanal [1982], Analysis of satellite images- National Institute of Aeronautics and Space / LAPAN [2002], Indonesian Institute of Science (LIPI) Publication [1972], Report on Regional Government/ Laporan Pemerintah Daerah [2004], The United Nation Groups of Experts on Geographical names (UNGEGN) Report [1987], Circular of Chief Hydro-Oceanography Division - Indonesian Navy or Kadishidros TNI-AL (2012), and Report on Geography and Toponimy Survey, National Committee on Topographic Names Standardization or Panitia Nasional Pembakuan Nama-nama Rupabumi [PPNR, 2010]. Such data sources published the number of island based on some citations from competent institutions, or based on the direct counting through research, like LAPAN. Then, the author compiles the numbers of islands in the form of Tables 1 as material for analysis.

Before doing analysis, the definition of island according to United Nation Convention on the Law of the Sea (UNCLOS) should become a reference. Article 121, Regime of Islands, the definition of island as follows:

1. An island is a naturally formed area of land, surrounded by water, which is above water at high tide.

2. Except as provided for in paragraph 3, the territorial sea, the contiguous zone, the exclusive economic zone and the continental shelf of an island are determined in accordance with the provisions of this Convention applicable to other land territory.

3. Rocks which cannot sustain human habitation or economic life of their own shall have no exclusive economic zone or continental shelf.

Based on definition of UNCLOS 1982, island is natural landform surrounded by waters (sea) above the sea level rise on the high tide. It means that in the highest sea tide, an island must be on the position of above water (always appeared and not sink land). For this context, to determine an island, sea level data are important. Geographical landforms that is sometimes appeared in surrounding waters and sometimes drowned, cannot be categorized as islands, according UNCLOS, and these would not impact to the international law.

\section{Result and Discussion}

As previously mentioned, the number of island in Indonesia, published from various sources and media are vary. This affect the difficulty for researches and analysts in finding the figures to be referred. The question is the variability of figure or numbers of island, which one is reliable. Several numbers of islands can be shown in Table 1.

Table 1 indicates that data sources derived from Ministry of Internal Affairs in the year 2004 [Departemen Dalam Negeri, 2004] published the figure of island number in Indonesia 17,504 islands. In 1987 Centre for Survey and Mapping - Indonesian Military Forces or Pusat Survei dan Pemetaan ABRI (Pussurta ABRI) published a number of 17,508 islands. Besides, Bakosurtanal, LIPI and Provincial Government still referred on the total figures that had been published so far. They just mentioned about the named and nonamed islands. Figure of named islands based on LIPI in 1972 were 6,127 islands, and after ten years, Bakosurtanal had reported the total number of 6,489 named islands (in the year of 1982).

LAPAN analyzed Landsat data to Indonesia to report that 18,108 islands were existed in the whole Indonesian territory [Kompas 5/3/2003] while as mentioned in Table 1 were 18,306 islands. However, this number is still verified because the limitation of remote sensing system to record objects in the earth surface, and also the interpretation can also be mistaken. In manual interpretation, besides as an important key of interpretation, shadow (from cloud) can sometimes deceive image interpreter in knowing island performance on satellite images.

The total island figure of 17,508 is calculated in the time of normal condition of sea level point. The present time, in fact, sea level rise tends to increase as impacted by many factors. Meaning that the decrease number of islands is not always taken or claimed by other country. In other word, the figure of 17,508 as a total number of Indonesian island may not be completely true [Kompas, 9/4/2015]. Even other opinion said that total figure of 17,508 islands is not true. Based on that reason, it was presented a new figure of 13,487 islands. The reason was that there was about 4 thousands of islands escaped based on the rule of international law of the sea (UNCLOS). The author has not found the reason of figure 13,487 islands. As known, in previous stage of calculation, and also done by LAPAN [2002] all appeared lands around the waters including sandbanks were counted as island. While, present calculation was based on the UNCLOS definition of island. Referring to UNCLOS, sandbanks cannot be classified as island so that the total numbers of island will be decreased about four thousand islands. To avoid different statements regarding on the numbers of total islands, Board of Geospatial Information (BIG) as a national authority should announce the national standard data on number of island. In 2017, BIG declared with 16.506 islands for Indonesia [Badan Informasi Geospasial /BIG, 2017]. 
Table 1. Comparative Figure of Total Number of Island in Indonesia

\begin{tabular}{|c|c|c|c|c|c|}
\hline \multirow{2}{*}{ Data Sources and Year } & \multicolumn{3}{|c|}{ Information on Island Number } & \multirow{2}{*}{$\begin{array}{l}\text { Media/ Source of } \\
\text { Publication }\end{array}$} & \multirow{2}{*}{ Remarks } \\
\hline & Island number & Named & Un-named & & \\
\hline \multirow[t]{2}{*}{ Depdagri 2004} & 17,504 & & & & \\
\hline & 17,508 & 7,870 & 9,634 & - & \\
\hline Pussurta ABRI, 1987 & 17,508 & 5,707 & & & $\begin{array}{l}\text { Including } 337 \text { island } \\
\text { names in the river. }\end{array}$ \\
\hline Bakosurtanal, 1982 & & 6,489 & & Gazetteers & $\begin{array}{l}\text { Including } 374 \text { island } \\
\text { names in the river. }\end{array}$ \\
\hline LAPAN, 2002 & 18,306 & & & $\begin{array}{l}\text { Satellite image } \\
\text { analysis }\end{array}$ & $\begin{array}{l}\text { Indocommunity- } \\
\text { blogspot.com }\end{array}$ \\
\hline LIPI, 1972 & & 6,127 & & Publication & \\
\hline $\begin{array}{l}\text { Regional Government, } \\
2004\end{array}$ & & 7,870 & 9,634 & $\begin{array}{l}\text { Reports from } \\
\text { Governors, Bupatis } \\
\text { and City Mayors . }\end{array}$ & \\
\hline $\begin{array}{l}\text { Bakosurtanal, (mentioned } \\
\text { by National Geographic } \\
\text { Indonesia (NGI) }\end{array}$ & $\begin{array}{l}\text { 17,506 (minus } \\
\text { two islands: } \\
\text { Sipadan and } \\
\text { Ligitan) }\end{array}$ & & & $\begin{array}{l}\text { www.Google.co.id } \\
\text { (mentioned as } \\
\text { official data) }\end{array}$ & \\
\hline \multirow[t]{3}{*}{$\begin{array}{l}\text { Bakosurtanal and the } \\
\text { University of Indonesia (UI) }\end{array}$} & & 11,013 & & NGI & $\begin{array}{l}\text { Verified by } \\
\text { Bakosurtanal }\end{array}$ \\
\hline & $17,508-18,306$ & 8,844 & & Wikipedia.orgh & $\begin{array}{l}922 \text { permanent islands } \\
\text { - inhabited. }\end{array}$ \\
\hline & 17,504 & & $\begin{array}{l}\text { About } 6,000 \\
\text { islands un- } \\
\text { inhabited }\end{array}$ & & \\
\hline CIA World Fact Book & 17,508 & & & & \\
\hline Ministry of Defence & 17,504 & & & & \\
\hline $\begin{array}{l}\text { Ministry of Marine and } \\
\text { Fishery } \\
\text { (MoMF), } 2011\end{array}$ & $+/-13,000$ & & & Verified by MoMF & $\begin{array}{l}\text { Director General } \\
\text { Marine, Coastal and } \\
\text { Small Islands (KP3K), } \\
\text { Sudirman Saad, when } \\
\text { visited Antara News. }\end{array}$ \\
\hline $\begin{array}{l}\text { Administrator Forum NGI, } \\
2011\end{array}$ & $\begin{array}{l}17,508 \\
\text { (possibility) }\end{array}$ & 5,707 & & & $\begin{array}{l}\text { Refer to UNGEGN } \\
\text { Report, } 1987\end{array}$ \\
\hline Th. Susatyo & $\begin{array}{l}\text { Someone said } \\
\text { 17,000and } \\
\text { someone else } \\
\text { said 13,000. } \\
\end{array}$ & & & & $\begin{array}{l}\text { Media mentioned } \\
\text { that Indonesia has not } \\
\text { agreed yet. }\end{array}$ \\
\hline $\begin{array}{l}\text { Division of Hydro- } \\
\text { Oceanography, Indonesian } \\
\text { Navy (TNI-AL) }\end{array}$ & 17,499 & 13,466 & 4,033 & $\begin{array}{l}\text { Circular Ka- } \\
\text { Dishidros No. } \\
\text { SE/1241/ IV/2012. }\end{array}$ & $\begin{array}{l}\text { Also reffered by } \\
\text { Investor Daily, } \\
\text { Thursday September, } \\
182014 \text {, time : } 17: 21\end{array}$ \\
\hline $\begin{array}{l}\text { National Committee } \\
\text { on Topographic Names } \\
\text { Standardization (PPNR) }\end{array}$ & 17,504 & 13,466 & $\begin{array}{l}\text { The rest can } \\
\text { be coral reef, } \\
\text { atoll etc. }\end{array}$ & $\begin{array}{l}\text { Field Verification } \\
\text { and Inventory } \\
\text { result. (Report } \\
\text { on Geographical } \\
\text { survey and } \\
\text { toponimy in 2010) }\end{array}$ & $\begin{array}{l}\text { Released at Kompas } \\
\text { at: 8-2-2012 source: } \\
\text { PPNR: Kemendagri, } \\
\text { Kemenhan, KKP, } \\
\text { Kemendiknas and } \\
\text { Bakosurtanal. }\end{array}$ \\
\hline $\begin{array}{l}\text { Board of Geospatial } \\
\text { Information (BIG) }\end{array}$ & & 16.056 & & $\begin{array}{l}\text { UNCSGN and } \\
\text { UNGEGN Meeting } \\
\text { in New York, } \\
\text { Agustus 7-18, } 2017\end{array}$ & $\begin{array}{l}\text { All } 16.056 \text { islands } \\
\text { were reported as } \\
\text { having names and } \\
\text { coordinates, and the } \\
\text { numbers are possible } \\
\text { to increase in the } \\
\text { future. }\end{array}$ \\
\hline
\end{tabular}

Compiled by Author - from various sources [2017] 
All recorded data and information related to islands should also be available in data base. Such island data base together with annotated bibliographic information are important to support the application of geographical information systems for the country's development [Martha, 1985, 1988].

Among various figures on island number mentioned on Table 1 above, the interesting figure 17,499 islands was published by Navy - Dishidros TNIAL [Kurnia, 2015]. From the aspect of competences and the duty, the figure was officially supported by Circular or Surat Edaran Kadishidros No. SE/1241/ IV/2012 [Dishidros TNI-AL., 2012]. The statement of Admiral Marsetio, Past Chief of Indonesian Navy Staff concerning Indonesian island strengthened the number of island mentioned [Lemhannas RI, 2015]. At least, this Circular bounded in the circle of Indonesian Army (TNI-AL) and Military Headquarter (Mabes TNI). Therefore, if the figure of 17,504 islands as result of National Committee on Topographic Names Standardization or Panitia Nasional Pembakuan Namanama Rupabumi (PPNR) which was formed through Presidential Decree or Perpres No. 112/2000, equipped by Ministerial Decree (Permendagri), still need to be harmonized with other institutions. Socialization and publication by one appointed Ministry or Authority are needed to avoid the differences of island number.

The big number of total islands indicates one of the main reason for Indonesia to be a strong, prosperous and developed maritime country. Indonesia has a total number of 17,504 islands (only 13,466 islands have been named and reported to UN) has a coastal line 95,181 $\mathrm{km}$. along (the second longest after Canada), and 75\% of the whole territory is sea area

$(5,8$ million square $\mathrm{km})$ including Indonesian Exclusive and Economic Zone (EEZ) (Geography dan Toponimy survey result, 2010).

The figure above becomes important due to the total number of island as an empirical number if kept and managed properly, it will contribute prosperity for the people [Dahuri, 2014]. The big figure on island number does not mean automatically become big country, as far as the figure or number of islands does not have a basic calculation and having good documentation and strong legal bases. Related to managing all islands, the number of island with their names has to be clearly identified and statistically informed. After establishment of Department of Marine and Fishery (DoMF) become Ministry of Marine and Fishery (MoMF) with Directorate General of Management of Small Islands, number of islands and also the outer islands where will have impacts for the national security should be paid into attention. The problem is related to the existing number of island has not yet been well documented. The good documentation in the form of Gazetteer and maps will help in avoiding many varieties of island number. National policy since the era of President Soesilo Bambang Yudhoyono, 'one-map policy' has strengthened one geospatial data source, and will result in one same figure about island number in Indonesia [Dishidros-TNI-AL, 2014].

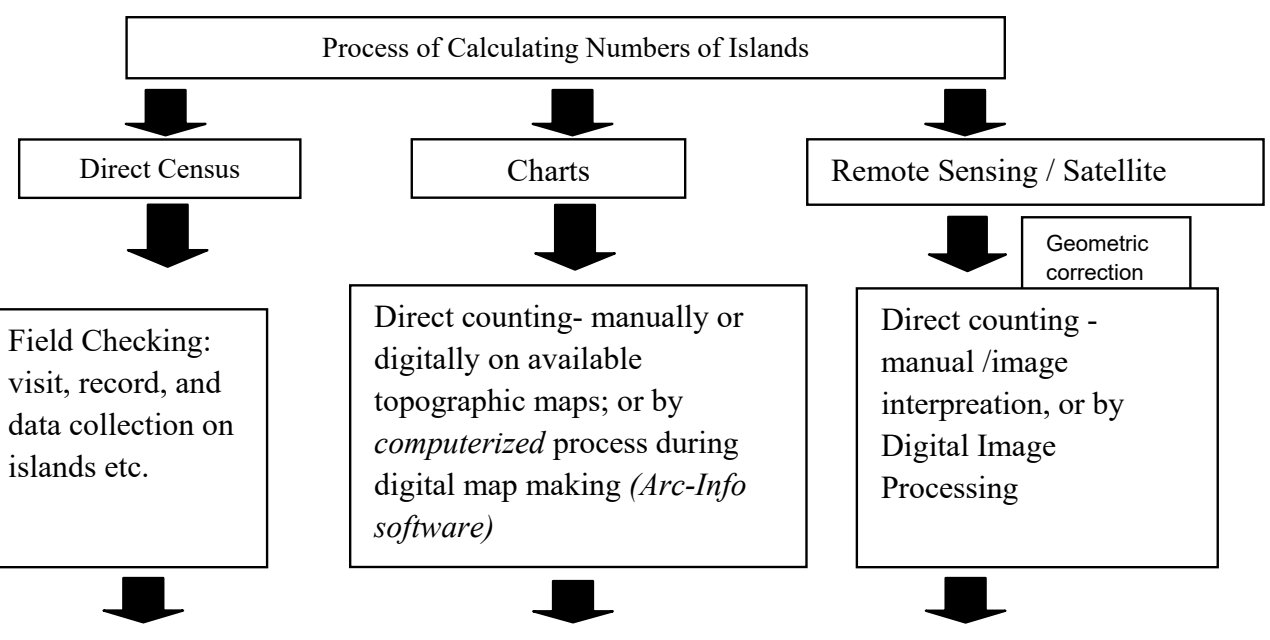

\begin{tabular}{|l|l|l|l|l|}
\hline Means & $:$ & $\begin{array}{l}\text { Survey ship, } \\
\text { survey instruments }\end{array}$ & On the table - is enough & $\begin{array}{l}\text { Laboratory and field checking to } \\
\text { validate data (sampling) }\end{array}$ \\
\hline Way & $:$ & Direct & $\begin{array}{l}\text { By maps that are not being up to } \\
\text { date. }\end{array}$ & $\begin{array}{l}\text { Relatively more } \text { up to date than } \\
\text { maps }\end{array}$ \\
\hline Result & $:$ & Objective & $\begin{array}{l}\text { Depends on map scale. The } \\
\text { larger scale will be more } \\
\text { accurate in calculation. }\end{array}$ & $\begin{array}{l}\text { Image classification is required to } \\
\text { avoid miss-interpretation. Image } \\
\text { resolution will influence the results } \\
\text { of island calculation. }\end{array}$ \\
\hline
\end{tabular}

Figure 1. Proposing the Estimation of Island Numbers 
The different numbers of island from various sources indicate the impacts of minimum socialization and question for the existing data reliability. Next, if compared, which figure can be reliable and how can calculate and obtain the accurate number of island in Indonesia. If President Jokowi will do field checking 'on the spot' every day for only one island for instance, having islands more than 17 thousands, the President needs more than 40 years to visit all. He has only limited time for 4 years of his presidency, or maximum 8 years if he will be re-elected. It means that there will be no enough time to visit all islands, as assets and part of the national territory. Therefore, the best way is to use technology like remote sensing in counting the number of islands.

The author proposes the estimation of total number of Indonesian islands can be conducted by three ways. Firstly, by direct census or counting islands by field or marine survey. Secondly, by calculating with the assistance of chart (map of the sea) as tool. Thirdly, by applying remote sensing imagery (Figure 1)

The first way, is actually the most accurate approach in collecting and counting total number of islands - by direct census with expensive cost and required many manpower to do that. This way should have a proper survey design to avoid the possibility in miss-counting, or double counting.

The second way, is to estimate the total number of island in Indonesia - by map assistance, particularly a reliable chart (map of the sea) with proper scale. Map/ chart users here involve with their capability in map reading. The old book of Erwin Raisz [1948], General Cartography discussed about 'Map Reading', as a part of the Chapter; even though it presented more on contour and landuse, Being used for the curriculum objectives in Hongkong, and presented samples of maps, graphic, pictures, diagrams that are more interesting because using description of 2 languages, English and Chinese, for understanding higher knowledge and detail (Cheung dan Cheung, 1980). However, the disadvantage of estimation on total number of islands through map is the availability of basemap itself related to islands. Map of National Marine Environment or Lingkungan Laut Nasional (LLN) published by BIG may not be enough as a tool for island estimation. Map of Coastal Environment of Indonesia or Lingkungan Pantai Indonesia (LPI) may also be the same as map of LLN. Large scale Charts or map of the sea published by Dishidros-TNI-AL can probably be used as a tool to count the island number. The larger scale of the map or chart, the better possibility to estimate total number of islands. In the contrary, the smaller scale of map or chart used, the smaller possibility in finding number of island. This is because maps with larger scale will perform of more detail island information.

The third way, is applying a vertical high resolution imagery. By using this remotely sensed data, the figures of island number will be obtained more accurately.
This is because satellite image can portrait all national territories seen as it is. This last way is considered as the most effective approach. This needs requirements, what is the real definition of island (according to United Nation Convension Law of the Sea/UNCLOS-1982), or in other terms that meaning of islands has to meet a definite criteria.

In 2002, LAPAN estimated the total number of island in Indonesia by using and analyzing remote sensing imagery. The study resulted total figure of Indonesian islands were 18.306. All objects visually seen on image including sandbanks are classified as island. For visual image interpretation, clouds cover can also be possibly miss-interpreted as island. As mentioned before, this way is the most effective method. The changes of existing islands can be monitored (if number of island is increased or decreased by high tide). Therefore, UNCLOS regulation can be accommodated with this approach. Off course, satellite image used has to be in high resolution and geometrically corrected so that remote sensing images have functioned properly to detect and count total number of island in Indonesia.

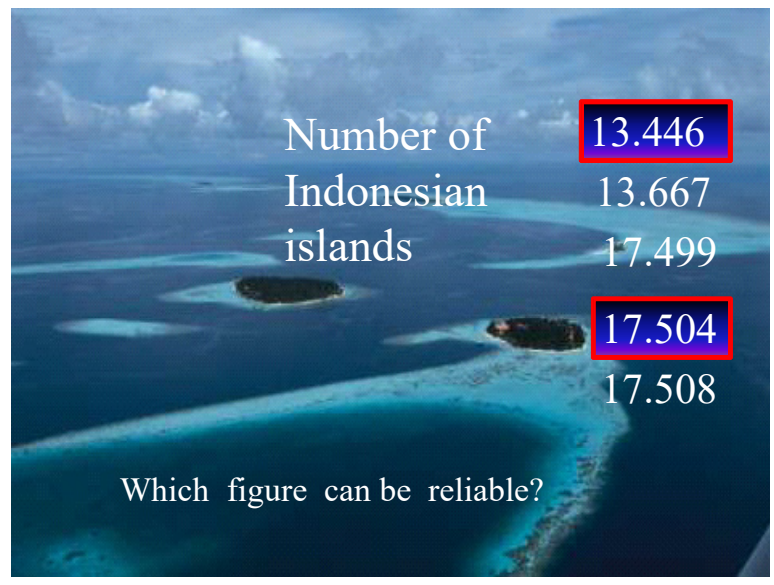

Karim [2009] with some modification.

Figure 2. Various numbers of Island, and which figure can be reliable?

From the above explanations and considering efficiency factor, the valid method to reanumerate or calculate the number of island is by high resolution remote sensing approach. Images that can be used to calculate number of island must be geometrically corrected so that the image will have similar scale with map. This method is valid because images can perform the real natural condition of island. The date of image recording can be known so that sea level rise in the condition of the low and high tide can also be known. Therefore, this way is the most effective and efficient (because the work does not require the direct visit or island census). This will provide the clear picture because vertical and high resolution image, as regulated by Presidential Instruction (Inpres) No. 6/ 2012 [Republik Indonesia, 2012]. From the comparison of 
figures - island number which is disseminated in many publication so far, the author concludes that a figure of islands number in Indonesia is 17.504 (13.466 named islands) is the best figure that can be as a reference. This figure can be used until the national agreement will find the better solution figure as a result of unanimous decision. Such figure is actually as a result of works of Panitia Nasional Pembakuan Nama-nama Rupabumi (PPNR) as mandate of Perpres no. 112 tahun 2000 [Republik Indonesia, 2000]. The member of PPNR consists of many Ministries or Institutions involved, including Ministry of Internal Affairs, Ministry of Defense (MoD), MoMF, Ministry of Education and Culture and Bakosurtanal (now well known as Geospatial Information Agency or Badan Informasi Geospasial / BIG). Because of limited socialization and publication, It recommends that PPNS should meet with all stakeholders - all members, and to involve Ministry of Agraria and Spatial Planning, LAPAN, Dishidros-AL and Lemhannas RI to re-committed and re-confirm and agree with only one figure or number of Island in Indonesia.

\section{Conclusion}

From this analysis, it concludes that one of the reliable approaches to validate some numbers of islands in Indonesia is analyzing geospatial information. The valid result in investigating the number of island depends on how accurate calculation of using high resolution geometrically corrected satellite imagery. This image has to perform as record product in the time of high tide condition. Therefore, the final result of islands counting will be relatively acceptable and can meet the island defined by UNCLOS 1982.

One Map Policy will be very important instrument in solving various geographical data and information problems in Indonesia. In this context, one geospatial data source, including number of island, can be act as one gate to release any data. In this case, one geospatial data source including the number of islands can be obtained from one map. For example, National Committee on Topographic Names Standardization or Panitia Nasional Pembakuan Nama-nama Rupabumi (PPNR) that BIG acts as Executive Secretary (Perpres No. 112/2000).

By one map policy, information related to various number of islands can be solved through a process of agreements among Department/ Institution involved and declared as one decision of formal and bounded governmental regulation.

\section{Acknowledgement.}

The author would like to say thanks for the support of Governor and Past Governor of Lemhannas RI, Prof. Dr. Budi Susilo Supandji, DEA, who always support all lecturers (Tajar), researchers (Taji) and professional staffs (Taprof) to write their works in the International Journal. The author also wants to say thanks to Prof. Dr. Enny Sudarmonowati and Prof. Dr. Erman Aminullah MA, as resource person in Workshop on Writing Scientific Publication, conducted by NUFFIC Project IDN-143 Lemhannas RI in June, 4 and 5 June 2015 for the improvement of this paper.

\section{References}

Abidin, Z.A. (2015). Inventarisasi Jumlah dan Potensi Pulau-Pulau di Indonesia, diunduh tanggal 29 Juni 2015, jam 14.15 dari situs http://geodesy.gd.itb. ac.id/hzabidin/?p=77. (in Bahasa Indonesia).

Badan Informasi Geospasial (BIG) dan Ikatan Geograf Indonesia (IGI). (2015). Paradigma Geomaritim: Strategi Mewujudkan Indonesia sebagai Poros Maritim Dunia dalam Perspektif Geografi, Cibinong, 2015. (in Bahasa Indonesia).

Badan Informasi Geospasial (BIG). (2017). Jumlah Pulau Indonesia Sebanyak 16.056 Pulau Masih Bisa Bertambah Lagi, http://www.big.go.id/beritasurta/. (in Bahasa Indonesia).

Cheung, R and E. Cheung. (1980). Modern Map Reading for Junior Secondary School, Jin Kung Educational Press, Hongkong, 1980.

Dahuri, R. (2014). Teologi Negara Maritim, Koran Sindo, Senin, 4 Agustus 2014. (in Bahasa Indonesia).

Departemen Dalam Negeri. (2004). Keputusan Menteri Dalam Negeri No. 109 A Tahun 2003 tentang Data Wilayah Administrasi Pemerintahan, Direktorat Jenderal Pemerintahan Umum, Jakarta- 2004. (in Bahasa Indonesia).

Dishidros-TNI-AL. (2012). Surat Edaran Kepala Dishidros Nomor SE/1241/IV/2012, tanggal 10 April 2012 tentang Data Wilayah NKRI. (in Bahasa Indonesia).

Dishidros-TNI-AL. (2014). Pulau Indonesia Berkurang Empat Ribu, diunduh dari situs http://www. kidnesia.com/Kidnesia2014/Dari-Nesi/SekitarKita/Pengetahuan-Umum/Pulau-IndonesiaBerkurang-4-Ribu . (in Bahasa Indonesia).

Karim, M. (2009). Eksistensi Pulau - Pulau Kecil di Kawasan Perbatasan Negara, Buletin Tata Ruang, Mei-Juni 2009. Badan Koordinasi Penataan Ruang Nasional (BKPRN), Jakarta 2009. (in Bahasa Indonesia).

Kompas. (2003). Jumlah Pulau di Indonesia Perlu Diverifikasi, Artikel - Penelitian/Research http:// www.coremap.or.id/print/article.php?id=163, Rabu, 05 Maret 2003. (in Bahasa Indonesia).

Kompas. (2015). Jumlah Pulau di Indonesia akan Didata Ulang, Kompas.com, 9 April 2015. (in Bahasa Indonesia). 
Kurnia, A. (2015). Percepatan Pembangunan Alur Pelayaran Tol Laut guna Mewujudkan Indonesia sebagai Poros Maritim Dunia dalam rangka Ketahanan Nasional, Kertas Karya Perorangan (Taskap) PPRA XX, 2015, Jakarta. (in Bahasa Indonesia).

Lemhannas RI. (2015). Pembangunan Sistem Keamanan Maritim sebagai Pendukung Kedaulatan NKRI Guna Mencapai Tujuan Nasional, Seminar Nasional PPRA LIII Lemhannas RI, 20 Oktober 2015. (in Bahasa Indonesia).

Mangan, C.M., Martha, S., Susanto, Al., Poniman, A. dan P. Kardono. (2013). Memperkokoh NKRI PerspektifGeografi, Penerbit Alvabet - Lemhannas RI, Jakarta, 2013.

Mangan, C.M., Martha, S., dan Al. Susanto. (2012). Peran Geografi untuk Memperkokoh NKRI, dalam Mangan, CM dkk. 2013. Memperkokoh NKRI PerspektifGeografi, Penerbit Alvabet - Lemhannas RI, Jakarta, 2013. (in Bahasa Indonesia).

Martha, S. (1985). An Annotated Bibliography on Geographic Information Systems Application in Developing Countries, The Indonesian Journal of Geography, vo. 15-16, no. 49-51, June 1985, pp. 133-143, Gadjah Mada University, Yogyakarta.

Martha, S., and M. Yulianto. (1988). Remote Sensing for Land Use Mapping of Bolango Sub River Basin, The Indonesian Journal of Geography, vo. 18, no. 55, June 1988, Gadjah Mada University, Yogyakarta.

Martha, S. (2006). Mengapa Pendekatan Geospasial Diperlukan dalam Pembangunan Negara Kepulauan, Prosiding Seminar Nasional PIT dan Kongres IGI, PSJ UI, Depok, 2006, pp. 112115 (ISBN 978-979-16609-0-7). (in Bahasa Indonesia).

Martha, S. (2012). Kesadaran Geografi (Geographical Awareness) dalam Rangka Kemandirian Bangsa, Ceramah pada Peserta Program Pendidikan Reguler Angkatan (PPRA) XLVIII Lembaga Ketahanan Nasional Republik Indonesia (Lemhannas RI), 2012. (in Bahasa Indonesia).

Martha, S. (2014). Kesadaran Geografi (Geographical Awareness) guna Peningkatan Kualitas Demokrasi, Ceramah pada Peserta Program Pendidikan Reguler Angkatan (PPRA) LI Lembaga Ketahanan Nasional Republik Indonesia (Lemhannas RI), 2014. (in Bahasa Indonesia).

Martha, S. (2013). Pembekalan 'Map' Reading Guna Peningkatan Kesadaran Geografis Para Peserta Pendidikan Kepemimpinan Tingkat Nasional Lemhannas RI dalam Rangka Ketahanan Nasional, Prosiding PIT XVI Ikatan Geograf Indonesia, Banjarmasin, 2-3 November 2013. (in Bahasa Indonesia).
Pailah, S.Y. (2009). Archipelagic State: Tantangan Perubahan Maritim, Klub Studi PerbatasanMenjaga Kedaulatan NKRI, Jakarta. (in Bahasa Indonesia).

Raisz, E. (1948). General Cartography, McGraw-Hill Book Company, Inc., New York.

Republik Indonesia. (2000). Peraturan Presiden no. 112 tahun 2000 tentang Panitia Nasional Pembakuan Nama-nama Rupabumi (PPNR), Jakarta. (in Bahasa Indonesia).

Republik Indonesia. (2012). Instruksi Presiden No. 6 Tahun 2012 tentang Penyediaan, Penggunaan, Pengendalian Kualitas, Pengolahan, dan Distribusi Data Satelit Penginderaan Jauh Resolusi Tinggi, Jakarta. (in Bahasa Indonesia).

Sebastian, L.C., Supriyanto, R.A. and I M. Arsana. (2015). Beyond the Archipelagic Outlook: the Law of the Sea, Maritime Security and the Great Powers, in Indonesia's Ascent: Power, Leadership and Regional Order (edited by Roberts, C.B., et all.), ISBN 978-1-137-39740-9, Palgrave-Macmillan, United Kingdom, 2015.

Suradinata, E. (2005). Hukum Dasar Geopolitik dan Geostrategi dalam Kerangka Keutuhan NKRI, Suara Bebas, Jakarta. (in Bahasa Indonesia).

United Nation Convension Law of the Sea (UNCLOS). (1982). Article 121, Regime of Islands.. 